\title{
Inseminating dose and water volume applied to the artificial fertilization of Steindachneridion parahybae (Steindachner, 1877) (Siluriformes: Pimelodidae): Brazilian endangered fish
}

\author{
Eduardo Antônio Sanches ${ }^{1,4}$, Danilo Caneppele ${ }^{2}$, Renan Yoshiharu Okawara ${ }^{3}$, Danielle \\ Zanerato Damasceno ${ }^{4}$, Robie Allan Bombardelli ${ }^{5}$ and Elizabeth Romagosa ${ }^{6}$
}

\begin{abstract}
The Steindachneridion parahybae is an endangered catfish from Brazil and strategies applied for gametes optimization are necessary. The aim of this study was to assess inseminating doses and water volume upon the fertilization, hatching rates and percentage of normal larvae in S. parahybae. Was used a randomized design in factorial scheme $(4 \times 4)$ with four inseminating doses: $1.0 \times 10^{4}, 1.0 \times 10^{5}, 1.0 \times 10^{6}, 1.0 \times 10^{7}$ spermatozoa oocyte ${ }^{-1}$ and four volumes of water: $1,35,65$ and $95 \mathrm{~mL}$ of water $\mathrm{g}^{-1}$ of oocytes. The combination of doses and volumes were performed in triplicates $(\mathrm{n}=48)$. Each incubator $(1.5 \mathrm{~L}$ of useful volume) with $1 \mathrm{~g}$ of oocytes was considered as an experimental unit. Significant interaction between inseminating doses and volumes of water to the values of the fertilization rates and quadratic effect of doses and volume for the values of hatching rates were observed. The doses and volumes did not influence the percentage of normal larvae (87.70 $\pm 5.06 \%)$. It is recommended the use of $5.5 \times 10^{6}$ spermatozoa oocyte $\mathrm{e}^{-1}$ and $1 \mathrm{~mL}$ of water $\mathrm{g}^{-1}$ of oocytes during in vitro fertilization procedure. These results allowed us to develop new biotechnological strategies applied to the conservation of S. parahybae.

O Steindachneridion parahybae é um bagre ameaçado de extinção no Brasil e estratégias aplicadas para a otimização de gametas são necessárias. O objetivo deste estudo foi avaliar doses inseminantes e volume de água sobre os valores das taxas de fertilização, eclosão e larvas normais em S. parahybae. Utilizando-se um delineamento experimental casualizado em esquema fatorial (4×4), com quatro doses inseminantes: $1,0 \times 10^{4} ; 1,0 \times 10^{5} ; 1,0 \times 10^{6} ; 1,0 \times 10^{7}$ espermatozóides ovócito $^{-1}$ e quatro volumes de água: $1 ; 35 ; 65$ e $95 \mathrm{~mL}$ de água $\mathrm{g}^{-1}$ de ovócitos. As combinações de doses e volumes foram realizadas em triplicatas $(\mathrm{n}=48)$. Cada incubadora $(1,5 \mathrm{~L}$ de volume útil) contendo $1 \mathrm{~g}$ de ovócitos foi considerada como uma unidade experimental. Interações significativas entre doses inseminantes e volumes de água para os valores das taxas de fertilização e efeito quadrático das doses e do volume para os valores das taxas de eclosão foram verificadas. As dosagens e os volumes aplicados não influenciaram no percentual de larvas normais $(87,70 \pm 5,06)$. Recomenda-se a aplicação de $5,5 \times 10^{6}$ espermatozoides ovócito ${ }^{-1}$ e a utilização de $1 \mathrm{~mL}$ de água. $\mathrm{g}^{-1}$ de ovócitos no procedimento de fertilização artificial in vitro. Estes resultados permitiram desenvolver novas estratégias biotecnológicas aplicadas na conservação do S. parahybae.
\end{abstract}

Keywords: Artificial reproduction, Freshwater fish, Oocytes, Sperm, Surubim-do-Paraíba.

\section{Introduction}

Steindachneridion parahybae (Steindachner, 1877) (Siluriformes: Pimelodidae), the surubim-do-Paraíba, is a endemic catfish to the Paraíba do Sul River basin (Garavello, 2005). The fish stock of this species in the wild has decreased greatly since the 1950s (Caneppele et al.,
2009; Hilsdorf \& Petrere Jr, 2002; Machado \& Abreu, 1952) mainly due to uncontrolled fishing and anthropic activities, such as dam construction and excess of pollution (Araujo et al., 2009). Steindachneridion parahybae is currently on the red list of Brazilian animals threatened with extinction (Caneppele et al., 2008), and is considered as regionally extinct in the state of São Paulo (PAN, 2011).

\footnotetext{
${ }^{1}$ Curso de Engenharia de Pesca. Universidade Estadual Paulista (UNESP), Av. Nelson Brihi Badur, 430, 11900-000 Registro, SP, Brazil. sanches@registro.unesp.br (corresponding author)

${ }^{2}$ Companhia Energética de São Paulo (CESP), Paraibuna, SP, Brazil. danilo.caneppele@cesp.com.br

${ }^{3}$ Consultoria Técnica em Aquicultura (MPA), Brasília, DF, Brazil.renanok@hotmail.com

${ }^{4}$ Centro de Aquicultura da UNESP (Caunesp), Jaboticabal, SP, Brazil. danizanerato@hotmail.com.

${ }^{5}$ Universidade Estadual do Oeste do Paraná (UNIOESTE), Toledo, PR, BR. rabombardelli@gmail.com.

${ }^{6}$ Instituto de Pesca - APTA, São Paulo, SP, Brazil. e.romagosa@uol.com.br.
} 
Caneppele et al. (2009) conducted the artificial reproduction of the $S$. parahybae by means of inducing agents, using the dry method for artificial fertilization (Ihering, 1937). The authors verified the ovulation in a period of 250 degree-hours with $85 \%$ of fertilized oocytes. These preliminary results have been used in recovery programs for the local fish fauna (Araújo, 2011; Honji et al., 2009; 2011; 2012; Sanches et al., 2014; 2015; Lopes et al., 2015). However, more studies about gamete characterization and reproductive management during the process of artificial fertilization, as well as about the reproductive biotechniques in captivity are necessary for the preservation of this species. They may contribute directly to the rational use of gametes, increasing the success of the artificial propagation, like the application of effective inseminating doses (Rurangwa et al., 2004).

Inseminating doses are unknown to the $S$. parahybae and were applied successfully in other species of native South American fish, providing suitable conditions to promote maximum fertilization: Salminus brasiliensis (Sanches et al., 2009; Weingartner, 2010), Rhamdia quelen (Bombardelli et al., 2006), Brycon insignis (Shimoda et al., 2007) and Piaractus mesopotamicus (Sanches et al., 2011a). The injection of suitable inseminating doses during the procedures of artificial fertilization brings important implications, such as higher values of fertilization rates, optimization of gametes and broodstocks, and also serves as basis for cryopreservation programs, allowing the thawing of the exact amount of spermatozoa that is necessary to fertilize the desired amount of oocytes (Bombardelli et al., 2006; Chereguini et al., 1999; Fogli da Silveira et al., 1988; Rurangwa et al., 1998; Sanches et al., 2011a; Sanches et al., 2009; Yasui et al., 2009).

Thus, the objective of this study was to evaluate the effect of inseminating doses and the water volume on the values of fertilization and hatching rates, as well as normal larvae in $S$. parahybae, kept in earthen ponds.

\section{Material and Methods}

Place and broodstock selection. The experiment was conducted at the Hydrobiology and Aquaculture Station of São Paulo Energy Company - EHA/CESP, in the town of

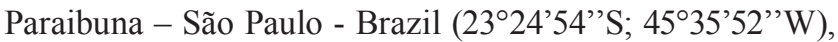
using $S$. parahybae broodstocks captured in the wild (F0), but maintained in captivity, and first generations (F1) of the fish farm station.

The fish, kept in two earthen ponds $\left(200 \mathrm{~m}^{2}\right)$, were fed twice a day, at 08:00a.m. and 4:00p.m., receiving predetermined amounts of extruded commercial feed for carnivorous fish, with $40 \%$ crude protein in the proportion of $3 \%$ of biomass day ${ }^{-1}$, before of reproductive period.

During the reproductive period (OctoberFebruary/2011-2012), brood stocks suitable for spawning in the tank after gentle pressure applied to the abdomen were selected. Males showing semen release and females with slightly bulged abdomen and which released a small amount of oocytes that were uniform in size (Caneppele et al., 2009) were chosen. In addition, a small amount of oocytes was withdrawn from the females via biopsy, using a $2.0 \mathrm{~mm}$ catheter and suction. That amount of oocytes was immersed in Serra solution (Lemanova \& Sakun, 1975), so that it was possible to verify the percentage of oocytes with germinal vesicle migration ( $\geq 65 \%$ of peripheral nucleus). Eight females $(1,350 \pm 661 \mathrm{~g})$, four F0 and four F1, and six males F0 $(1,659 \pm 550 \mathrm{~g})$ were selected. After the selection, the brood fish were transferred to the laboratory and kept in aquaria (500L) equipped with an aeration feature during $24 \mathrm{~h}$ (time necessary to the hormonal induction and artificial reproduction procedure). The water quality during this time was evaluated $\left(22.9 \pm 0.3^{\circ} \mathrm{C}, \mathrm{pH} 7.6 \pm 0.66 .8 \pm 0.1 \mathrm{mg}\right.$ of dissolved oxygen $\mathrm{L}^{-1}$ ).

For future verification, voucher-specimens from the same local were collected and stored in the fish collection of the Zoological Museum of São Paulo University - MZUSP, with catalog number 100672 and 108433.

Hormonal induction. The hormonal induction of all females was conducted by means of injections of two doses of crude carp pituitary extract (CCPE): the first dose consisted of $0.5 \mathrm{mg}$ of CCPE kg-1, and the second one, of $5.0 \mathrm{mg}$ of CCPE kg-1 at an interval of 12 hours, diluted in saline $(0.9 \% \mathrm{NaCl})$, as proposed by Caneppele et al. (2009). The doses of hormone were injected intramuscularly in the upper portion of the dorsal fin. Based in fact that the CCPE does not provide increase on sperm production and quality (Caneppele et al., 2015), the males were not submitted to the process of hormonal induction.

Collection and evaluation of semen and sperm characteristics. For the semen collection, the fish were restrained, dried (cloth and paper towel), and submitted to abdominal pressure from head to tail. The first drop of semen was discarded to avoid possible contamination with urine. The rest of the semen was collected in graded test tubes $( \pm 0.1 \mathrm{~mL})$, and then kept at room temperature $\left(\approx 25^{\circ} \mathrm{C}\right)$. The contamination of the samples with blood and urine was avoided at the moment of semen release.

Analyses of sperm concentration, morphological changes of the spermatozoa and sperm viability were conducted in accordance with Sanches et al. (2009). Furthermore, the computerized analysis of sperm motility was conducted as proposed by Sanches et al. $(2010 ; 2013)$.

Two samples of semen mixing "pool" were used to measure sperm concentration. In each one, $5 \mu \mathrm{L}$ of the semen diluted in $5,000 \mu \mathrm{L}$ of buffered formol-saline were used, resulting in a dilution of 1:1,000. A Neubauer hematimetric chamber was used for the sperm cell count (spermatozoa. $\mathrm{mL}^{-1}$ ) (Sanches et al., 2011b).

Three slides with spermatozoa stained with rose bengal (Streit Jr. et al., 2004) were prepared using the same semen fixed in formol-saline to assess the possible 
morphological changes of the spermatozoa. In order to do so, the methodology employed by Streit Jr. et al. (2006) and Bombardelli et al. (2010) for slide making was adapted. $500 \mu \mathrm{L}$ of spermatozoa+buffered formol-saline (dilution 1:1,000 of spermatozoa: fixative) were kept in Eppendorf tubes $(1.5 \mathrm{~mL})$, to which $10 \mu \mathrm{L}$ of stain were added. After homogenization, $10 \mu \mathrm{L}$ of fixative + spermatozoa + stain were placed on one end of the glass slide. The slide was then inclined at an angle of $45^{\circ}$ so that the droplet could run to the other end. The slides were dried in open air, and then analyzed under light microscope (obj. 40×) (Hafez \& Hafez, 2004), with the evaluation of at least 200 spermatozoa (CBRA, 1998).

Sperm viability was assessed by the staining method eosin-nigrosin (Blom, 1950), using $30 \mu \mathrm{L}$ of semen, $90 \mu \mathrm{L}$ of eosin yellow (3\%) and $90 \mu \mathrm{L}$ of nigrosin $(5 \%)$. After the slides had been processed, 200 spermatozoa (CBRA, 1998) were analyzed under light microscope (obj. 40×) (Sanches et al., 2009), where the stained spermatozoa were considered dead and the colorless ones were considered alive (Kavamoto \& Fogli da Silveira, 1986).

The evaluation of sperm motility by the computerized method was carried out as described by Wilson-Leedy \& Ingermann (2007) and adapted for neotropical catfishes by Sanches et al. (2010; 2013), using free software. The process of activation was conducted in Eppendorf tubes $(1.5 \mathrm{~mL})$, using $1 \mu \mathrm{L}$ of semen and $1,000 \mu \mathrm{L}$ of water from the incubation system. The images were obtained by a Nikon trinocular light microscope (model e50i), previously focused (obj. 10×), attached to a Prosilica GE680c camera (http:// www.alliedvisiontec.com), and connected to a computer (intel core i $7^{\circ} \mathrm{CPU} 2.3 \mathrm{GHz}, 4 \mathrm{~Gb}$ Ram), operational system Microsoft Windows $7^{\circ}$. The videos were captured by the software AVTUniversalPackage at 101fps (640x480 pixels) in *avi format, edited with the software VIRTUALDUB-1.9.0 (virtualdub.org), and exported as image sequence in *.jpg format to a specific directory. The corresponding images were opened, edited in IMAGEJ (National Institutes of Health, USA, http://rsbweb.nih.gov/ij/) and compiled by means of the plugin CASA (University of California and Howard Hughes Medical Institute, USA, http://rsbweb.nih. gov/ij/plugins/casa.html).

The videos were processed based on the description of the necessary components for the use of the application CASA via free software (Wilson-Leedy \& Ingermann, 2006). However, the configurations used were adapted for the species (Sanches et al. 2013). The sperm parameters obtained from four replications were: motility rate (MOT), curvilinear velocity (VCL), average path velocity (VAP), straight-line velocity (VSL), straightness (STR) and progression (PROG).

The amount of motile spermatozoa per milliliter of semen was estimated based on the previous assessment of the sperm quality. These results were used to estimate the dosage of semen according to the amount of motile spermatozoa. Therefore, semen from only two males F0 $(1,950 \pm 495 \mathrm{~g})$ that had presented over $80 \%$ of motile cells was used and mixed to form the "pool" of semen used in fertilization assay. This procedure was employed to avoid the negative effects on fertilization rate. The semen collected from other four males was discarded due to its poor quality.

Collection and evaluation of oocytes. The oocytes were collected after a period of 320 degree-hours (14h after second hormonal induction and water at $22.9^{\circ} \mathrm{C}$ ), registered from the last hormonal injection onward (Caneppele et al., 2009; Okawara et al., 2015). Sample was performed by stripping, which consists of gentle abdominal massage in cephalocaudal direction. The oocytes were collected in a porcelain mortar, and then weighed $( \pm 0.1 \mathrm{~g})$ for the estimate of the number of oocytes produced per gram of female. However, for the estimate of the total number of oocytes in each experimental unit, four sub-samples of 1 gram of oocytes from each female were counted.

After the oocyte stripping, a subjective (macroscopic) quality check, with regard to size uniformity, yellow color and absence of blood was used as prerequisite. Thirty grams of oocytes from each female were then homogenized, originating a sample consisting of a pool of oocytes that was then used in the experiment of fertilization. Based in subjective characterization of high quality (size and uniform color, without blood and ovulation on same time), oocytes from only two females F0 $(2,300 \pm 424 \mathrm{~g})$ were used. A batch of $1 \mathrm{~g}$ of oocytes was immersed in Gilson solution (Simpson, 1951) for the assessment of oocyte diameter (stereomicroscope, $20 \times$ ). For the fertilization, pre-established amounts of oocytes, chosen according to the weight $(1 \mathrm{~g})$ were employed.

Experimental design. The inseminating doses (spermatozoa oocyte $^{-1}$ ) and water volume ( $\mathrm{mL} \mathrm{g}^{-1}$ of oocytes) employed were determined by three pilot experiments.

The selected gametes were distributed in a factorial experimental design $4 \times 4$. The treatments consisted of four inseminating doses of $1.0 \times 10^{4}, 1.0 \times 10^{5}, 1.0 \times 10^{6}$ and $1.0 \times 10^{7}$ spermatozoa oocyte ${ }^{-1}$, four water volumes of 1,35 , 65 and $95 \mathrm{~mL}$ of water $\mathrm{g}^{-1}$ of oocytes and three replications (48 experimental units). A conic hatchery (1.5L of useful volume) containing $1.0 \mathrm{~g}(287 \pm 7)$ of fertilized oocytes with their respective inseminating doses (dosed with automatic micropipettes) and water volume was considered as one experimental unit. In order to minimize the effect of the size of the container on the water volume, the fertilizations were performed in different plastic cups with the following volumes: $50,100,150$ and $200 \mathrm{~mL}$ for the respective water volumes $1,35,65$ and $95 \mathrm{~mL} \mathrm{~g}^{-1}$ of oocytes.

Artificial fertilization. The artificial fertilization of $S$. parahybae oocytes was conducted using the dry method (Ihering, 1937) with gametes homogenization in the absence of water. The water of the artificial incubation system was added later for gamete activation, with the pre-established qualities and amounts described above. 
After the artificial fertilization, the eggs were transferred to experimental hatcheries $(1.5 \mathrm{~L})$ with enough water flow to keep the eggs moving, in a $300 \mathrm{~L}$ system of water recirculation. The temperature, $\mathrm{pH}$, oxy-reduction potential, electrical conductivity, dissolved oxygen, oxygen saturation and total dissolved solids were monitored by the device Horiba (Model U-50).

Eleven hours after the fertilization, corresponding to the end of the epibolic movement or closure of the blastoporus (Honji et al., 2012), the percentage of fertilized eggs was estimated based on the count of all the eggs from each experimental unit. The translucid eggs that presented an apparently normal embryonic development were considered as fertilized, and the unfertilized eggs (=addled) were opaque or white. After the eggs had hatched (1,320 degree-hours), the values of the hatching rates were estimated. In order to do so, all the newly hatched larvae from each experimental unit were anesthetized with benzocaine $\left(50 \mathrm{mg} . \mathrm{L}^{-1}\right)$ for 30 seconds, for later classification into normal and abnormal under stereomicroscope (10×).

Statistical analysis. The possible influence of the inseminating doses (ID) and water volume (WV) on the response variables (RV) was assessed by means of the response surface model:

$$
\mathrm{RV}=\partial_{0}+\partial_{1} \mathrm{ID}+\partial_{2} \mathrm{WV}++\partial_{3}(\mathrm{ID} * \mathrm{WV})+\partial_{4}(\mathrm{ID})^{2}+\partial_{5}(\mathrm{WV})^{2}+\varepsilon
$$

where: $\partial i=$ constants; $\mathcal{E}=$ error with $\sim N\left(0, \partial^{2}\right)$

The non-significant parameters $(\mathrm{P}>0.05)$ were progressively removed according to higher-order terms by the backward stepwise method. The assumptions were followed as suggested by Myers (1990) and Quin \& Keough (2002). The analyses were conducted by means of the Statistica $\subseteq$ software (Statsoft, 2005). The maximum lines were plotted in 3D and 2D graphs from partial derivatives of the statistical model in relation to the significant variables.

\section{Results}

Females released $73.55 \pm 7.00 \mathrm{~g}$ of oocytes, corresponding to a fecundity of $9,418 \pm 2,610$ oocytes $\mathrm{kg}^{-1}$ of brood fish. Soon after the stripping, the oocytes exhibited an average diameter of $1.70 \pm 0.07 \mathrm{~mm}$. The water quality parameters assessed are shown in Table 1, and the semen and sperm parameters in Table 2.

Values of fertilization rate presented interaction effect $(\mathrm{P}<0.05)$ between the inseminating doses and applied volume of water (Fig. 1). The highest values could be verified in the application of the inseminating doses of $5.4 \times 10^{6}$ spermatozoa oocyte $^{-1}$ in $1.0 \mathrm{~mL}$ of water $\mathrm{g}^{-1}$ of oocytes, up to $6.4 \times 10^{6}$ spermatozoa oocyte ${ }^{-1}$ in $95.0 \mathrm{~mL}$ of water $\mathrm{g}^{-1}$ of oocytes (Fig. 1). At intermediate volumes (x), the highest values of fertilization rate may be found with the inseminating dose (y) obtained by the equation $y=5,423,431.90+10,674.42 * x$ (Fig. 1 ).
Table 1. Measured parameters of the quality of the water used in the fertilization of oocytes and incubation of the Steindachneridion parahybae eggs (mean \pm standard deviation).

\begin{tabular}{lc}
\hline Parameters & Values \\
\hline Temperature $\left({ }^{\circ} \mathrm{C}\right)$ & $22.96 \pm 0.41$ \\
$\mathrm{pH}$ & $7.07 \pm 0.17$ \\
Oxy-reduction potential $(\mathrm{ORPmV})$ & $308.07 \pm 13.08$ \\
Electrical conductivity $\left(\mathrm{m} \mathrm{cm}^{-1}\right)$ & $0.04 \pm 0.03$ \\
Dissolved oxygen $\left(\mathrm{mg} \mathrm{L}^{-1}\right)$ & $6.19 \pm 0.47$ \\
Oxygen saturation $(\%)$ & $74.06 \pm 5.46$ \\
Total dissolved solids $\left(\mathrm{g} \mathrm{L}^{-1} \mathrm{TDS}\right)$ & $0.03 \pm 0.02$ \\
\hline
\end{tabular}

Table 2. Semen and sperm parameters in Steindachneridion parahybae (mean \pm standard deviation).

\begin{tabular}{lc}
\hline Parameters & Values \\
\hline Collected volume $(\mathrm{mL})$ & $26.80 \pm 7.07$ \\
Relative volume $\left(\mathrm{mL} \mathrm{kg}^{-1}\right)$ & $14.68 \pm 7.35$ \\
Motility rate $(\%)$ & $87.10 \pm 6.69$ \\
Curvilinear velocity $\left(\mu \mathrm{m} \mathrm{s}^{-1}\right)$ & $132.71 \pm 11.99$ \\
Average path velocity $\left(\mu \mathrm{m} \mathrm{s}^{-1}\right)$ & $103.65 \pm 11.32$ \\
Straight line velocity $\left(\mu \mathrm{m} \mathrm{s}^{-1}\right)$ & $91.06 \pm 9.05$ \\
Straightness $(\%)$ & $87.94 \pm 1.79$ \\
Progression $(\mu \mathrm{m})$ & $3.870 \pm 372$ \\
Sperm concentration $\left(\mathrm{espermatozoa} \mathrm{mL}^{-1}\right)$ & $1.70 \times 10^{10}$ \\
Sperm viability $(\%)$ & $88.83 \pm 4.86$ \\
Normal spermatozoa $(\%)$ & $52.49 \pm 1.54$ \\
\hline
\end{tabular}

The behavior of the values of hatching rate was similar to the behavior of the fertilization rate. However, no interaction between the inseminating doses and the water volume was verified, only quadratic effect $(\mathrm{P}<0.05)$ (Fig. 2). The highest hatching rates were found with the inseminating dose of $5.5 \times 10^{6}$ spermatozoa oocytes ${ }^{-1}$, independently of the water volume (Fig. 2). As verified for the fertilization rate, the lowest water volume promoted the highest hatching rates $(\mathrm{P}<0.05)$ (Fig. 2).

The percentage of normal larvae $(87.70 \pm 5.06 \%)$ did not suffer influence of the dose and volume $(\mathrm{P}>0.05)$.

\section{Discussion}

The sperm production found in this study was higher than the one verified for the same species by Caneppele et al. (2015) and the computerized sperm characteristics were higher than the ones verified by Sanches et al. (2013) for fresh semen, and by Araújo (2011) for cryopreserved semen. Therefore, the results obtained in this study were considered satisfactory for artificial reproduction carried out in laboratory routines. Egg production and diameter were similar to the ones found by Caneppele et al. (2009), with production between 9,000 and 10,000 oocytes $\mathrm{kg}^{-1}$ of female and diameter around $1.90 \mathrm{~mm}$. 

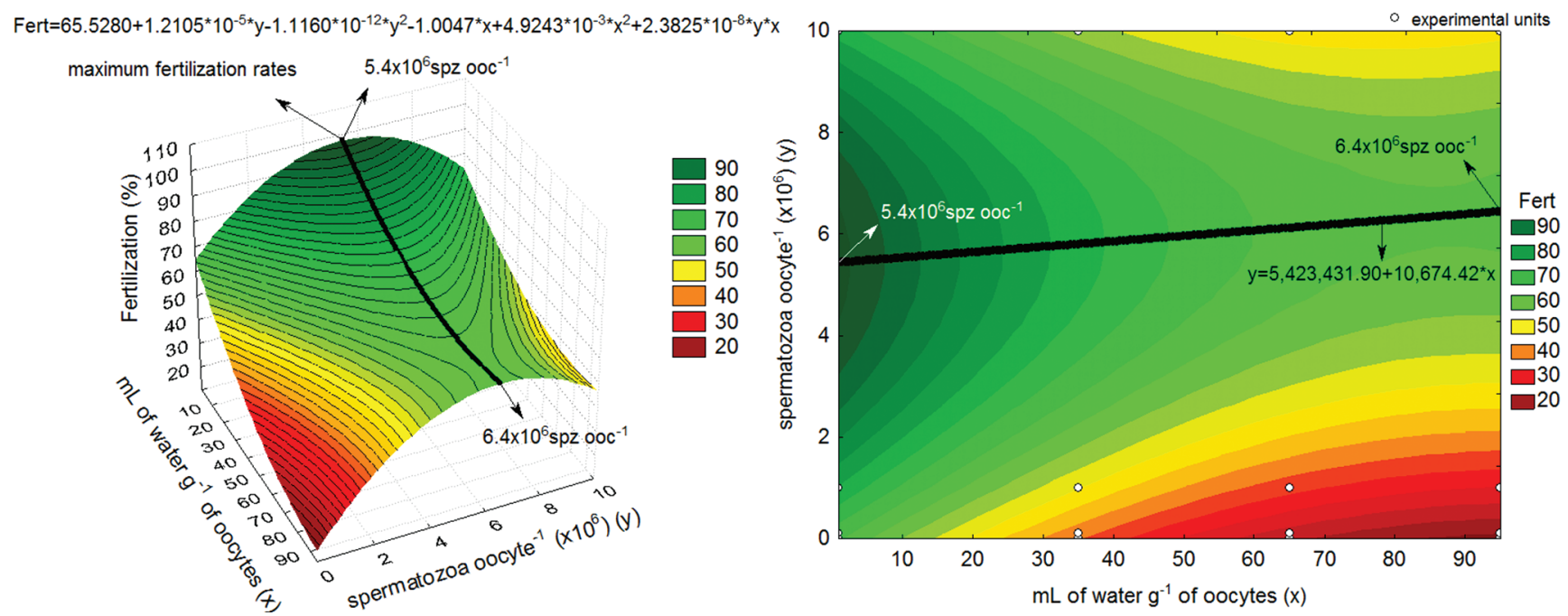

Fig. 1. Values of fertilization rates (Fert) of Steindachneridion parahybae with regard to different inseminating doses versus water volume. Left - 3D graphical representation. Right - 2D graphical representation. Spermatozoa oocyte ${ }^{-1}\left(\mathrm{spz} \mathrm{ooc}^{-1}\right)$. $\mathrm{r}^{2}=77.47 \%$.
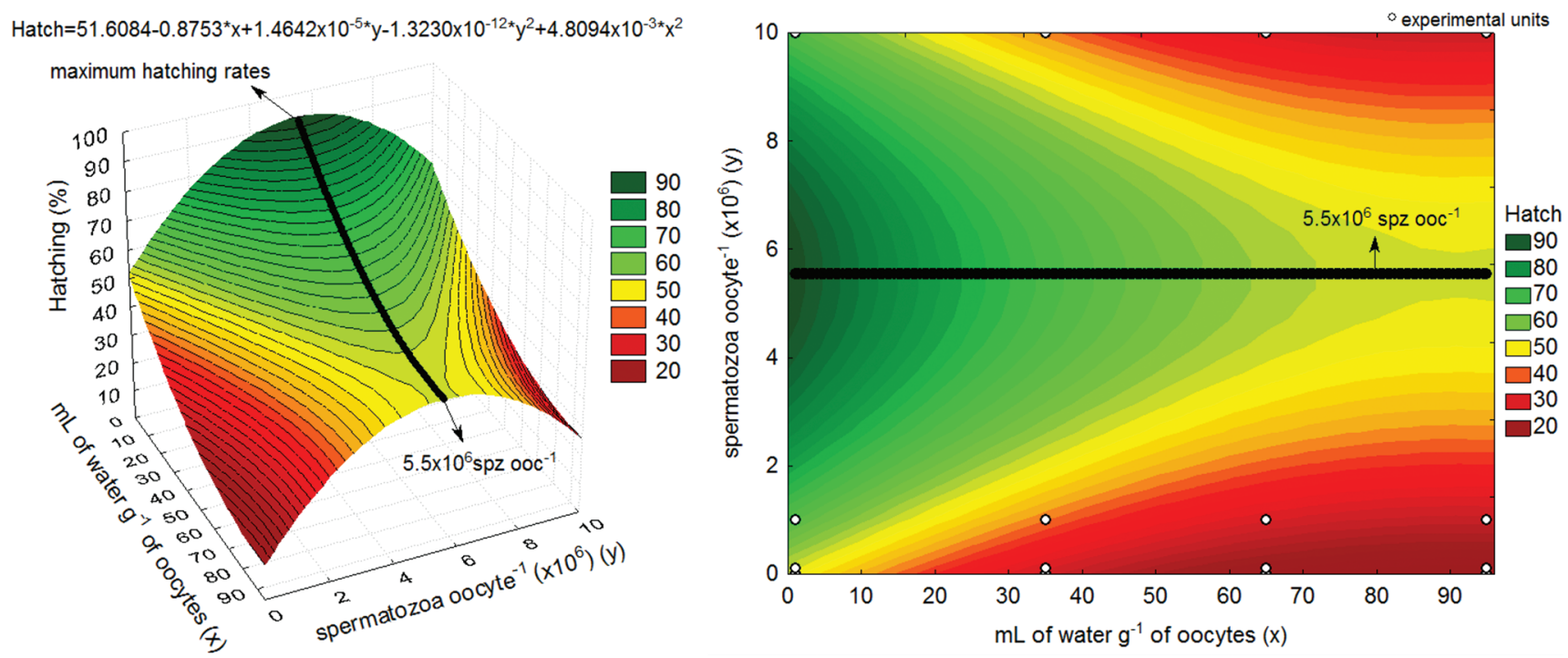

Fig. 2. Values of hatching rate (Hatch) of Steindachneridion parahybae with regard to different inseminating doses versus water volume. Left $-3 \mathrm{D}$ graphical representation. Right $-2 \mathrm{D}$ graphical representation. Spermatozoa oocytes ${ }^{-1}\left(\mathrm{spz} \mathrm{ooc}^{-1}\right)$.

The behavior of the fertilization and hatching rates observed in the present experiment was different from what had been observed in other species of native South American fish: for the Brycon insignis, Shimoda et al. (2007) verified a plateau behavior of the values of fertilization rate from the dosage of $3.1 \times 10^{5}$ spermatozoa oocyte $^{-1}$ onward. Sanches et al. (2009), studying Salminus brasiliensis, observed quadratic behavior, with better doses in the application of $3.1 \times 10^{4}$ spermatozoa oocyte ${ }^{-1}$. When studying the Piaractus mesopotamicus, Sanches et al. (2011a) observed influence in the values of fertilization rate only at super dosages of semen. The authors verified that the inseminating dose of $7.0 \times 10^{7}$ spermatozoa oocyte ${ }^{-1}$ reduced the values of the rates when compared to the dosages between $7.0 \times 10^{3}$ and $7.0 \times 10^{6}$ spermatozoa oocyte ${ }^{-1}$.
Authors also verified that the water volume influenced on the rates, since when there was little water in the procedure $\left(0.5 \mathrm{~mL} \mathrm{~mL}^{-1}\right.$ of oocytes), it affected the values of fertilization rate negatively, and the use of 15 to $60 \mathrm{~mL}$ $\mathrm{mL}^{-1}$ of oocytes did not interfere with the results. The use of large amounts of water in procedures of artificial fertilization was also reported by Weingartner (2010) for $S$. brasiliensis, increasing the fertilization rate in four times in the application of 50 instead of $10 \mathrm{~mL}^{10 \mathrm{~g}^{-1}}$ of oocytes. The use of large amounts of water may help with the dilution of some toxic components, such as magnesium, calcium and potassium (from the ovarian fluid or the use of cryoprotectants), which at certain amounts may cause reduction of the sperm quality and consequently lower fertilization (Yasui et al., 2012). 
We found that the use of large amounts of water negatively influenced the values of fertilization and hatching rates, and the volume of $1.0 \mathrm{~mL} \mathrm{~g}^{-1}$ of oocytes was the most recommended. The use of large amounts of water might have diluted the inseminating medium excessively, so even with large amounts of spermatozoa, it might have provided an inappropriate condition for the sperm entry in the micropyle (Chereguini et al., 1999; Sanches et al., 2009).

Despite the fact that lower volumes have provided better fertilization rates, it is not recommended to use lower volumes than the minimum value tested in the present experiment $\left(1.0 \mathrm{~mL} \mathrm{~g}^{-1}\right.$ of oocytes), because such volumes might compromise the sperm activation and later, the fertilization rates (Billard \& Cosson, 1992).

Best values of fertilization and hatching rates were estimated with sperm dosages around $5.5 \times 10^{6}$ spermatozoa oocyte $^{-1}$. However, ideal dosages may vary according to the quality of the gametes (Bobe \& Labbe, 2010), and the procedure employed to achieve fertilization (Rurangwa et al., 2004).

The curvilinear velocity (VCL) and the average path velocity (VAP) are factors that may influence the fertilization of the S. parahybae (Araújo, 2011). This author observed a positive linear correlation between those velocities and the values of fertilization, indicating that faster spermatozoa present better chances of reaching the micropyle before its closure, or before their movement stops completely. Therefore, it is assumed that spermatozoa that exhibit circular movements show higher fertilization capacity. This hypothesis is corroborated by Tused et al. (2008), who verified positive correlation between the values of fertilization rate and VCL, and negative correlation with the straight line velocity (VSL) for Oncorhynchus mykiss. These results indicate that the lower the VSL, the higher the values of fertilization, since the VSL is indicative of straightness (positive correlation) (Tuset et al., 2008).

In general, the time of sperm activation in freshwater fish is short. This is therefore another factor that might influence the values of fertilization rate (Cosson, 2010). Caneppele et al. (2015), studying S. parahybae, observed that the time necessary for approximately $50 \%$ of the spermatozoa to lose their motility was $38.76 \pm 0.74$ seconds, and that after around one minute all of them stopped moving. The use of specific activators may ensure longer time of sperm motility for the $S$. parahybae (Araújo, 2011). Nevertheless, their influence on the values of fertilization rate is unknown.

Furthermore, other factors may vary, such as oocyte diameter, because the larger the oocyte diameter, the more spermatozoa are necessary to surround the perimeter of the oocyte and reach the micropyle. That fact may be observed when compared with other species, such as Rhamdia quelen, which exhibits oocytes with average diameter from $1.0 \mathrm{~mm}$ (Pereira et al., 2006) to $1.5 \mathrm{~mm}$ (Amorim et al., 2009), 1,1410ocytes $\mathrm{g}^{-1}$ and minimum inseminating dose of $8.9 \times 10^{4}$ spermatozoa oocyte $^{-1}$ (Bombardelli et al., 2006). Sanches et al. (2010), studying the same species, observed the VAP of $58.67 \pm 9.01 \mu \mathrm{m} \mathrm{s}^{-1}$ and progression of $1,202.80 \pm 163.89 \mu \mathrm{m} 15$ seconds after activation, unlike $S$. parahybae, which despite exhibiting larger eggs, also exhibits higher values of VAP and PROG, and even so needs higher inseminating doses. Therefore, more studies are necessary to clarify those effects on the species.

The values of fertilization and hatching rates verified with the inseminating doses and water volumes tested in the present experiment revealed important effects on the artificial reproduction of the $S$. parahybae. New studies will be able to contribute to the reproductive efficiency for the utilization of genetic material, maximization of the broodstocks and use of cryopreservation programs. Furthermore, they will also contribute to studies on the characterization of gametes and their possible influence on fertilization.

In conclusion, the highest oocyte fertilization and egg hatching rates for $S$. parahyba may be obtained with the use of an inseminating dose of $5.5 \times 10^{6}$ spermatozoa oocyte $^{-1}$, and water volume of $1.0 \mathrm{~mL} \mathrm{~g}^{-1}$ of oocytes, corresponding to each $10 \mathrm{~g}$ of oocytes, $10 \mathrm{~mL}$ of water and $1.0 \mathrm{~mL}$ of semen.

\section{Acknowledgements}

Authors would like to thank the employees of the Hydrobiology and Aquaculture Station of the São Paulo Energy Company (CESP) in the town of Paraibuna, São Paulo, Brazil and the São Paulo Research Foundation FAPESP (grant number: 2009/18609-6 and 2010/02818-5), and the National Council for Scientific and Technological Development - CNPq (grant number 478347/2009-0).

\section{References}

Amorim, M. P., B. V. Campos Gomes, Y. S. Martins, Y. Sato, E. Rizzo \& N. Bazzoli. 2009. Early development of the silver catfish Rhamdia quelen (Quoy \& Gaimard, 1824) (Pisces: Heptapteridae) from the Sao Francisco River Basin, Brazil. Aquaculture Research, 40: 172-180.

Araujo, F. G., B. C. Teixeira Pinto \& T. P. Teixeira. 2009 Longitudinal patterns of fish assemblages in a large tropical river in southeastern Brazil: evaluating environmental influences and some concepts in river ecology. Hydrobiologia, 618: 89-107.

Araújo, R. V. 2011. Motilidade, velocidade e fertilidade do sêmen de surubim-do-paraíba Steindachneridion parahybae (Siluriformes) criopreservado em diferentes diluidores. Unplubished Ph.D Dissertation, Universidade Federal de Lavras, Lavras, 91p.

Billard, R. \& M. P. Cosson. 1992. Some problems related to the assessment of sperm motility in fresh-water fish. Journal of Experimental Zoology, 261: 122-131.

Blom, E. 1950. A One-minute live-dead sperm stain by means of Eosin-Nigrosin. Fertility and Sterility, 1: 176-177.

Bobe, J. \& C. Labbé. 2010. Egg and sperm quality in fish. General and Comparative Endocrinology, 165: 535-548. 
Bombardelli, R. A., C. Hayashi, M. R. M. Natali, E. A. Sanches \& P. A. Piana. 2010. Digestible energy level on reproductive and zootechnical performance and lipids deposition in hepatocytes of the Nile tilapia males. Revista Brasileira de Zootecnia, 39: 941-949.

Bombardelli, R. A., E. F. Mörschbächer, R. Campagnolo, E. A. Sanches \& M. A. Syperreck. 2006. Insemination dose for artificial fertilization of grey jundia oocytes, Rhamdia quelen (Quoy \& Gaimardm, 1824). Revista Brasileira de Zootecnia, 35: $1251-1257$.

Caneppele, D., E. A. Sanches \& E. Romagosa. 2015. Sperm production of Steindachneridion parahybae (Steindachner, 1877) an the effect of hormonal induction throughout one reproductive cycle. Journal of Applied Ichthyology, 31: 54-61.

Caneppele, D., R. M. Honji, A. W. S. Hilsdorf \& R. G. Moreira. 2009. Induced spawning of the endangered Neotropical species Steindachneridion parahybae (Siluriformes: Pimelodidae). Neotropical Ichthyology, 7: 759-762.

Caneppele, D., P. Pompeu \& J. Garavello. 2008. Steindachneridion parahybae (Steindachner, 1876). Pp. 236-238. In: Machado, A. B. M., G. M. Drummond \& A. P. Paglia (Eds.). Livro Vermelho da Fauna Brasileira Ameaçada de Extinção. 1.ed. Brasília, Ministério do Meio Ambiente.

CBRA. 1998. Manual para exames andrológicos e avaliação de sêmen animal. 2. ed. Belo Horizonte, Colégio Brasileiro de Reprodução Animal, 49p.

Chereguini, O., I. G. de la Banda, I. Rasines \& A. Fernandez. 1999. Artificial fertilization in turbot, Scophthalmus maximus (L.): different methods and determination of the optimal spermegg ratio. Aquaculture Research, 30: 319-324.

Cosson, J. 2010. Frenetic activation of fish spermatozoa flagella entails short-term motility, portending their precocious decadence. Journal of Fish Biology, 76: 240-279.

Fogli da Silveira, W., E. T. Kavamoto, M. G. Rigolino \& Y. A. O. Tabata. 1988. Fertilidade do sêmen de truta arco-íris, Salmo irideus gibbons, em diferentes concentrações de espermatozóides por óvulo. Boletim do Instituto de Pesca, 15: 51-54.

Garavello, J. C. 2005. Revision of genus Steindachneridion (Siluriformes: Pimelodidae). Neotropical Ichthyology, 3: 607623.

Hafez, E. S. E. \& B. Hafez. 2004. Reprodução animal. 7. ed. Barueri, Manole, 530p.

Hilsdorf, A. W. S. \& M. Petrere Jr. 2002. Conservação de peixes na bacia do rio Paraíba do Sul. Ciência Hoje, 30: 62-65.

Honji, R. M., D. Caneppele, A. W. S. Hilsdorf \& R. G. Moreira. 2009. Threatened fishes of the world: Steindachneridion parahybae (Steindachner, 1877) (Siluriformes: Pimelodidae). Environmental Biology of Fishes, 85: 207-208.

Honji, R. M., D. Caneppele, M. Pandolfi, F. Lo Nostro \& R. G. Moreira. 2011. The brain-pituitary axis structure in captivity reared females of Steindachneridion parahybae (SILURIFORMES). Indian Journal of Science and Technology, 4: 30-31.

Honji, R. M., C. E. Tolussi, P. H. Mello, D. Caneppele \& R. G. Moreira. 2012. Embryonic development and larval stages of Steindachneridion parahybae (Siluriformes: Pimelodidae) - implications for the conservation and rearing of this endangered Neotropical species. Neotropical Ichthyology, 10: 313-327.

Ihering, R. V. 1937. A method for inducing fish to spawn. The Progressive Fish-Culturist, 34: 15-16.
Kavamoto, E. \& W. Fogli da Silveira. 1986. Características físicas, químicas e microscópicas do sêmen do bagre, Rhamdia hilarii. Boletim do Instituto de Pesca, 13: 95-100.

Lemanova, N. A. \& O. F. Sakun. 1975. Metodisceskoe posibie pogor monalnoi stimulacji proizvoditielei karpa pré rannom polucenii licinok. Izvestiya Gosudartvennogo Nauchno Issledivatel Skogo Instituta, 88: 3-23.

Lopes, T. S., E. A. Sanches, R. Y. Okawara \& E. Romagosa. 2015. Chilling of Steindachneridion parahybae (Siluriformes: Pimelodidae) embryos. Theriogenology, 84: 538-544.

Machado, C. E. M. \& H. C. F. Abreu. 1952. Notas preliminares sobre a caça e a pesca no Estado de São Paulo - I. A Pesca no Vale do Paraíba. Boletim de Indústria Animal, 13: 145-160.

Myers, R. H. 1990. Classical and modern regression with applications. 2. ed. Belmont, Duxbury Press, 488p.

Okawara, R. Y., E. A. Sanches, D. Caneppele, D. Z. Damasceno \& E. Romagosa. 2015. Ovulation and initial rearing of Steindachneridion parahybae (Siluriforme: Pimelodidae) larvae from different accumulated thermal units. Ichthyological Research, 62: 1-9.

Polaz, C. N. M., Y. S. L. Bataus, A. Desbiez, M. L. Reis (Eds.). 2011. Plano de ação nacional para a conservação das espécies aquáticas ameaçadas de extinção da Bacia do Rio Paraíba do Sul. Brasilia, Instituto Chico Mendes de Conservação da Biodiversidade, ICMBio, 140p.

Pereira, C. R., L. J. G. Barcellos, L. C. Kreutz, R. M. Quevedo, F. Ritter \& L. B. Silva. 2006. Embryonic and larval development of jundiá (Rhamdia quelen Quoy \& Gaimard, 1824, Pisces, Teleostei), a South American catfish. Brazilian Journal of Biology, 66: 1057-1063.

Quinn, G. P. \& M. J. Keough. 2002. Experimental design and data analysis for biologists. New York, Cambridge University Press, 537p.

Rurangwa, E., D. E. Kime, F. Ollevier \& J. P. Nash. 2004. The measurement of sperm motility and factors affecting sperm quality in cultured fish. Aquaculture, 234: 1-28.

Rurangwa, E., I. Roelants, G. Huyskens, M. Ebrahimi, D. E. Kime \& F. Ollevier. 1998. The minimum effective spermatozoa: egg ratio for artificial insemination and the effects of mercury on sperm motility and fertilization ability in Clarias gariepinus. Journal of Fish Biology, 53: 402-413.

Sanches, E. A., R. A. Bombardelli, D. M. Baggio \& B. E. de Souza. 2009. Insemination dose for artificial fertilization of dourado oocytes. Revista Brasileira de Zootecnia, 38: 2091-2098.

Sanches, E. A., R. A. Bombardelli, R. M. Marcos, G. Neumann, C. P. R. de Toledo \& E. Romagosa. 2010. Sperm motility of Rhamdia quelen studied using computer-assisted analysis by open-source software. Aquaculture Research, 42: 153-156.

Sanches, E. A., D. M. Baggio, P. A. Piana, B. E. de Souza \& R. A. Bombardelli. 2011a. Artificial fertilization of oocytes and sperm activation in pacu: effects of the spermatozoa:oocyte ratio, water volume, and in natura semen preservation. Revista Brasileira de Zootecnia, 40: 1-6.

Sanches, E. A., R. M. Marcos, D. M. Baggio, L. Tessaro, R. E. Balen \& R. A. Bombardelli. 2011b. Sperm concentration estimate of fish semen using spermatocrit method. Revista Brasileira de Zootecnia, 40: 1163-1167.

Sanches, E. A., R. M. Marcos, R. Y. Okawara, D. Caneppele, R. A. Bombardelli \& E. Romagosa. 2013. Sperm motility parameters for Steindachneridion parahybae based on opensource software. Journal of Applied Ichthyology, 29: 11141122 . 
Sanches, E. A., R. Y. Okawara, D. Caneppele, G. Neumann, R. A. Bombardelli \& E. Romagosa. 2014. Storage of Steindachneridion parahybae oocytes at different temperatures. Aninal Reproduction Science, 151: 262-268.

Sanches, E. A., R. Y, Okawara, D. Caneppele, C. P. R. Toledo, R. A. Bombardelli \& E. Romagosa. 2015. Sperm characteristics of Steindachneridion parahybae (Steindachner, 1877) throughout $112 \mathrm{~h}$ of storage at four temperatures. Journal of Applied Ichthyology, 31: 79-88.

Shimoda, E., D. R. Andrade, M. V. Vidal Júnior, H. P. Godinho \& G. S. Yasui. 2007. Determination of the optimum ratio of spermatozoa per oocyte of the piabanha Brycon insignis. Arquivo Brasileiro de Medicina Veterinaria e Zootecnia, 59: 877-882.

Simpson, A. C. 1951. The fecundity of the plaice. Fish Investigation, 17: 1-27.

Stastoft, I. 2005. Statistic (data analysis software system) Version 7.1, STATSOFT.

Streit Jr., D. P., R. P. Ribeiro, G. V. Moraes, L. V. Mendez, J. M. Gallo, M. Digmayer \& J. A. Povh. 2006. Características qualitativas do sêmen de pacu (Piaractus mesopotamicus) após indução hormonal. Bioscience Journal, 22: 119-125.

Streit Jr., D. P., G. V. Moraes, R. P. Ribeiro, J. A. Povh, E. D. Souza \& C. A. L. Oliveira. 2004. Avaliação de diferentes técnicas para coloração de sêmen de peixes. Arquivos de Ciências Veterinárias e Zoologia da Unipar, 7: 157-162.

Tuset, V. M., G. J. Dietrich, M. Wojtczak, M. Slowińska, J. de Monserrat \& A. Ciereszko. 2008. Relationships between morphology, motility and fertilization capacity in rainbow trout (Oncorhynchus mykiss) spermatozoa. Journal of Applied Ichthyology, 24: 393-397.
Weingartner, M. 2010. Aperfeiçoamento das técnicas de fertilização de ovócitos de dourado, Salminus brasiliensis Cuvier, 1816 (Characiformes: Characidae), utilizando sêmen fresco e congelado durante o processo de reprodução induzida. Unpublished Ph.D. Dissertation, Universidade Federal de Santa Catarina, Florianópolis, 81p.

Wilson-Leedy, J. G. \& R. L. Ingermann. 2006. Manual for CASA plugin for Image J. Avaliable from: http://rsbweb.nih.gov/ij/ plugins/docs/CASAinstructions.pdf. (Acess: 18 August 2011).

Wilson-Leedy, J. G. \& R. L. Ingermann. 2007. Development of a novel CASA system based on open source software for characterization of zebrafish sperm motility parameters. Theriogenology, 67: 661-672.

Yasui, G. S., L. Arias-Rodriguez, T. Fujimoto \& K. Arai. 2009. A sperm cryopreservation protocol for the loach Misgurnus anguillicaudatus and its applicability for other related species. Animal Reproduction Science, 116: 335-345.

Yasui, G. S., T. Fujimoto, L. Arias-Rodriguez, Y. Takagi \& K. Arai. 2012. The effect of ions and cryoprotectants upon sperm motility and fertilization success in the loach Misgurnus anguillicaudatus. Aquaculture, 344: 147-152.

Submitted October 22, 2014

Accepted January 14, 2016 by Bernardo Baldisserotto 